\title{
Long Non-Coding RNAs: Rising Regulators of Plant Reproductive Development
}

\author{
Tongtong Yu and Hongliang Zhu * (C) \\ College of Food Science and Nutritional Engineering, China Agricultural University, Beijing 100083, China; \\ ttyu@cau.edu.cn \\ * Correspondence: hlzhu@cau.edu.cn; Tel.: +86-10-62737571
}

Received: 26 October 2018; Accepted: 20 January 2019; Published: 26 January 2019

check for updates

\begin{abstract}
Long non-coding RNAs (lncRNAs) exert a multitude of functions in regulating numerous biological processes. Recent studies have uncovered a growing number of lncRNAs within the plant genome. These molecules show striking tissue-specific expression patterns, suggesting that they exert regulatory functions in the growth and development processes of plants. Plant reproductive development is tightly regulated by both environmental and endogenous factors. As plant reproductive development is a crucial aspect of crop breeding, lncRNAs that modulate reproductive development are now particularly worth regarding. Here, we summarize findings that implicate lncRNAs in the control of plant reproductive development, especially in flowering control. Additionally, we elaborate on the regulation mechanisms of lncRNAs, tools for research on their function and mechanism, and potential directions of future research.
\end{abstract}

Keywords: long non-coding RNAs; reproductive development; flowering time; molecular regulatory mechanisms

\section{Introduction}

Plant reproduction is essential for flowering plants to pass on genetic traits to the next generations, and it begins with the transition from vegetative to reproductive growth [1-3]. Flowering is a key factor controlling the production of seed and fruit, and both environmental and endogenous factors are involved in regulating flowering time [4,5]. In recent years, studies have shown that many long non-coding RNAs (lncRNAs) can be identified in plants and play regulatory roles in reproductive development [6]. Long non-coding RNAs (lncRNAs) are non-coding RNAs of more than 200 nucleotides, which can play important roles in epigenomic regulation, gene transcription, and expression of protein-coding genes [7]. Initially regarded as "noise" within the genome, lncRNAs have attracted increasing research interest, and several lncRNAs have been functionally characterized at transcriptional and post-transcriptional levels [8-10]. LncRNAs can be regarded as gene regulatory factors, especially in the diagnosis and prognosis of human diseases [11-16]. In plants, the identification of lncRNAs typically receives more attention than research on functions and mechanisms, although continuously emerging studies report specific developmental expression patterns which suggest potentially important biological functions [17-19]. Here, we summarize recent findings on the study of lncRNAs associated with plant flowering and reproductive development, and their regulatory mechanisms. Furthermore, we discuss the technology and potential future research strategies for studying lncRNAs in this field. 


\section{Identification and Specific Expression Pattern of Plant lncRNAs}

Studies on plant lncRNA functions are still at an early stage compared to those on lncRNAs in humans and animals $[20,21]$. So far, a large number of lncRNAs have been identified from different kinds of plants. (Table 1 ).

Table 1. List of long non-coding RNAs (lncRNAs) identified in plants.

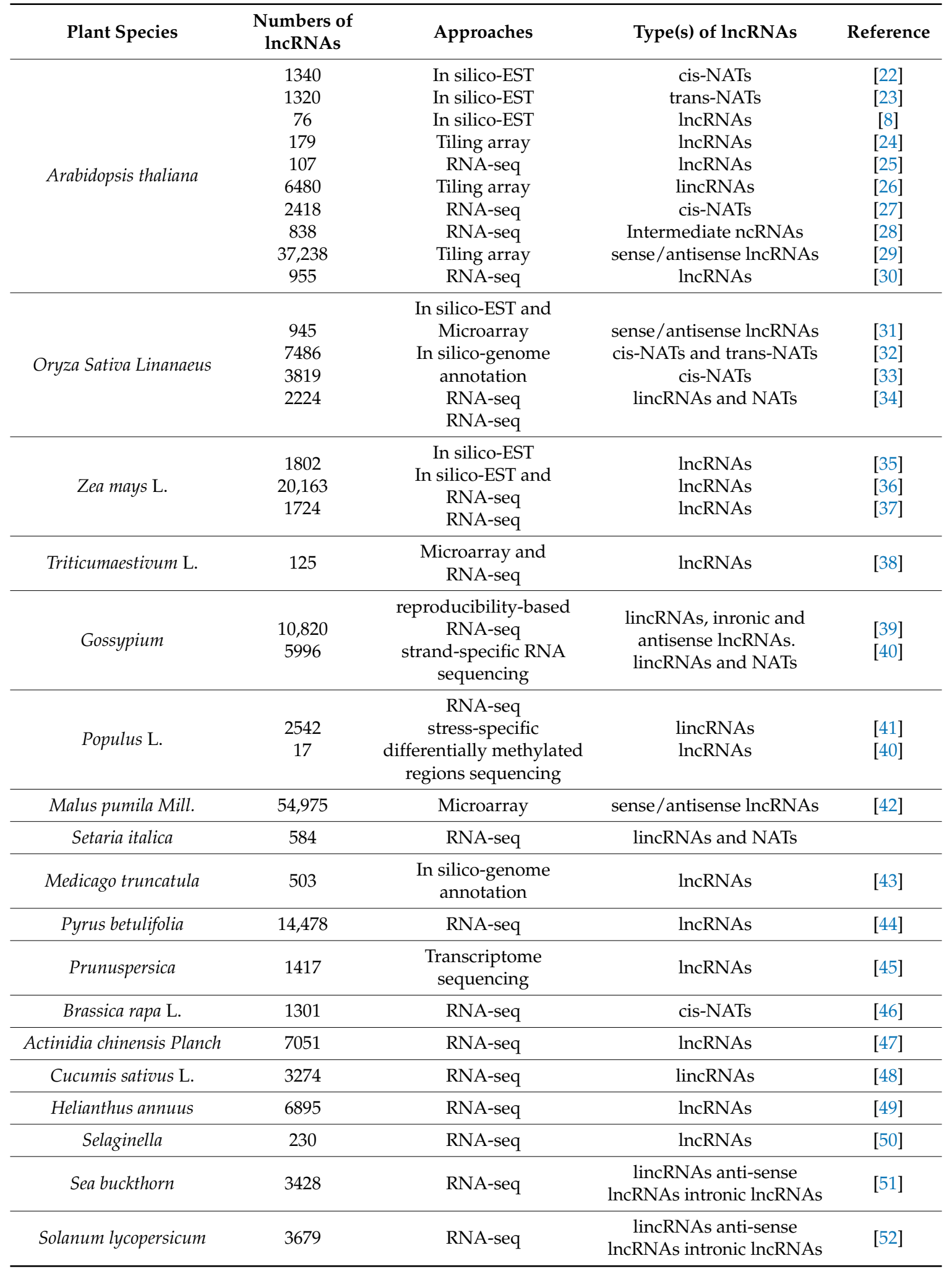


Current research to identify novel lncRNAs mainly depends on genome-wide transcriptomics, such as DNA microarrays and RNA sequencing [53]. Most plant lncRNAs can be divided into different types, such as intergenic, intronic, sense, and natural antisense lncRNAs (Table 1). The large number of identified lncRNAs shows significant changes in different organs or during stress, suggesting that they are dynamically regulated and might function in development and stress responses [26]. Based on 200 Arabidopsis thaliana transcriptomic versions available from databases, a total of 6480 lncRNAs were identified by either organ-specific or stress-induced expression [26]. In maize, 38 lncRNAs were imprinted from full-length cDNA sequences, which were defined by their different relative expression substantially between maternal and paternal alleles [54]. LncRNAs involved in antifungal networks of Arabidopsis thaliana were identified using a powerful tool for IncRNA identification, strand-specific RNA sequencing analysis [55]. A total of $245 \operatorname{lncRNAs}$ with poly(A) tails and 58 IncRNAs without poly(A) tails were identified, which were expressed differentially in Arabidopsis thaliana seedlings under four stress conditions [56]. RNA sequencing combined with transcriptome analysis was used to identify 2224 tissue-specific lncRNAs in rice, 600 of which were natural antisense transcripts (NATs) [41]. In Populus trichocarpa, 2542 drought-responsive long intergenic non-coding RNAs (lincRNAs) were identified by RNA sequencing [41]. In maize and rice, non-directional and strand-specific RNA sequencing experiments were used to profile numerous lncRNAs which were derived from conserved genomic regions. Protein-coding genes flanking or having a sense-antisense relationship to these conserved lncRNAs were mainly involved in development and stress responses, suggesting that the associated lncRNAs might have similar functions [57]. In Solanum commersonii, 18,882 lncRNAs were identified by computational modelling predictions and RNA sequencing [58]. In wheat, 125 putative stress-responsive lncRNAs were identified by computational and experimental analyses [59]. In rice, 5515 lncRNAs were also identified during the transition from seed to mature embryo [60]. Comparative transcriptome analysis identified a total of 300 differentially expressed genes (DEGs) and 254 differentially expressed lncRNAs (DELs) between wild-type and vernalized Brassica rapa [61]. In Solanum lycopersicum, 3679 lncRNAs were discovered by RNA sequencing, and of them, 677 lncRNAs were significantly differentially expressed in ripening mutant fruits, indicating that IncRNAs could be involved in the regulation of fruit ripening [52]. In a recent study, we unraveled 627 lncRNAs as direct targets of the tomato ripening-related transcription factor RIN in a genome-wide range using chromatin immune-precipitation sequencing combined with RNA deep sequencing, and one of these lncRNAs has been shown to be involved in fruit ripening [62].

The most obvious similarities between the identified lncRNAs from different plant species are high tissue-specific expression patterns, suggesting that lncRNAs might play a specific regulatory role in plant development. Although many studies have reported the functions of lncRNAs, there are great necessities to further develop the study on the function and mechanism of IncRNAs [29,41,63-67] (Table 2).

Table 2. The plant tissue-specific lncRNAs and their biological functions.

\begin{tabular}{ccccc}
\hline Name & Species & Tissue Specificity & Biological Function & Refs. \\
\hline AtR8 & Arabidopsis thaliana & Root & Hypoxic stress & {$[63]$} \\
\hline CsM10 & Cucumis sativus L. & Apices of seedlings & Sex differentiation & {$[64]$} \\
\hline GmENOD40 & Giycine max & Nodule & Nodule formation & {$[66]$} \\
\hline OsENOD40 & Oryza sativa L. & Stem & Nodule formation & {$[67]$} \\
\hline Zm401 & Zea mays & Pollen & Fertility & {$[68]$} \\
\hline \multirow{2}{*}{ asHSFB2a } & Arabidopsis thaliana & $\begin{array}{c}\text { Female } \\
\text { gametophyte }\end{array}$ & $\begin{array}{c}\text { Vegetative and } \\
\text { gametophytic development }\end{array}$ & {$[65]$} \\
\hline
\end{tabular}




\section{Regulation Mechanisms of lncRNAs in Plant Reproductive Development}

As a new class of regulator, the mechanisms of lncRNA regulation are shown to be complicated and various, with the growth in functional researches on lncRNAs $[69,70]$. Research on the interactions between IncRNAs and DNA, microRNAs (miRNAs), or other molecules has become popular, and lncRNA regulatory mechanisms pose substantial difficulties for the study of cancer and inflammatory diseases [71-73]. In these regulatory processes, IncRNAs interact with other biological molecules in several mechanistic properties, such as decoys, scaffolds, guides, and signals [74]. According to studies in plant reproductive development, the regulation mechanisms of lncRNAs can be summarized as follows: First, lncRNAs can compete with miRNAs to target genes and participate in regulating the accumulation of target genes, which is termed endogenous target mimicries (eTMs) [75]. Recently, this mechanism has been previously shown for plant lncRNAs to apparently induce transcription factors, proteins, or microRNAs as decoys or molecular sponges in a target mimicry mechanism, and thus indirectly regulate the transcription and expression of target genes [75-78]. Research on competing endogenous RNAs (ceRNAs) in plants started later, but so far has shown the similarities to animals and human cells. LncRNA induced by phosphate starvation 1 was the first discovered eTM in plants, which controlled phosphorus balance in plants by sponging miR399 to dissolve its bond with target genes $[75,76]$. In Arabidopsis thaliana and in rice, genome-wide analyses have identified eTMs from intergenic or noncoding genes sponging 20 miRNAs, including miR156, miR159, miR160, miR166, and miR172 [75]. In addition, the IncRNAs XLOC_0063639 and XLOC_007072 were identified and confirmed to effectively sponge miR160 and miR166 from their mRNA, thereby controlling floral and seed development in plants [75]. In addition to miRNAs, several lncRNAs have been shown to interact with short interfering RNAs (siRNAs). For example, Long day specific male fertility associated RNA (LDMAR) has been found to generate an siRNA, Psi-LDMAR, which can cause RNA-dependent DNA methylation (RdDM) and lead to repression of $L D M A R$ [79]. For example, the siRNA osa-smR5864w, derived from lncRNA P/TMS12-1, counts 21 nucleotides (nt) and was identified in rice. The siRNA osa-smR5864w can trigger photoperiod-sensitive and temperature-sensitive male sterile rice [80]. Over 700 lncRNAs which were specifically enriched in floral organs can generate phased small interfering RNAs (phasiRNAs). The $21 \mathrm{nt}$ phasiRNAs are induced by a cleavage with miR2118, and play important roles in reproductive stages of rice [81].

LncRNAs can also serve as guides that bind to chromatin-modifying enzymes, guide lncRNAribonucleoprotein complexes to specific target regions, and elicit changes of chromatin structure in local regions. Cold induced long antisense intragenic RNA (COOLAIR) regulates the expression of FLOWERING LOCUS C (FLC), which belongs to a type of transcriptional regulation [82]. So far, the most common model of the lncRNAs regulatory mechanism is as scaffolds to guide the assembly of different types of molecular complexes in the target region, and forming ribonucleoprotein complexes to play a coordinated regulatory role $[66,83]$. A good example is the plant lncRNA cold of winter-induced noncoding RNA from the promoter (COLDAIR), which can bind with polycomb repressive complex 2 (PRC2) complex protein CURLY LEAF (CLF) and recruit it to the FLC locus, leading to the deposition of histone chromatin marker H3K27 trimethylation (H3K27me3) [6]. COLDAIR can both act as a scaffold in recruiting PRC2 complexes and a guide in targeting PRC2 to specific sites, which illustrates the diversity of lncRNAs' biological functions, addressing that some lncRNAs can regulate gene expression in more than one way [82]. Therefore, as more biological mechanisms of lncRNA are revealed, the lncRNA-protein interaction is constantly updated.

\section{Function of IncRNAs in Regulation of Plant Reproductive Development}

Researchers pay great attention to plant lncRNAs, which is greatly attributed to the discovery of the relationship between lncRNAs and plant flowering [84]. An increasing number of plant lncRNAs from different species have been identified in recent years $[38,39,45,85,86]$. However, knowledge of their biological functions is relatively limited. At present, research on lncRNA functions in plant reproductive development is mainly limited to plant flowering and pollen development. Here, 
we summarize recent studies on lncRNAs that modulate plant reproductive development by a diversity of pathways, as shown in Figure 1.

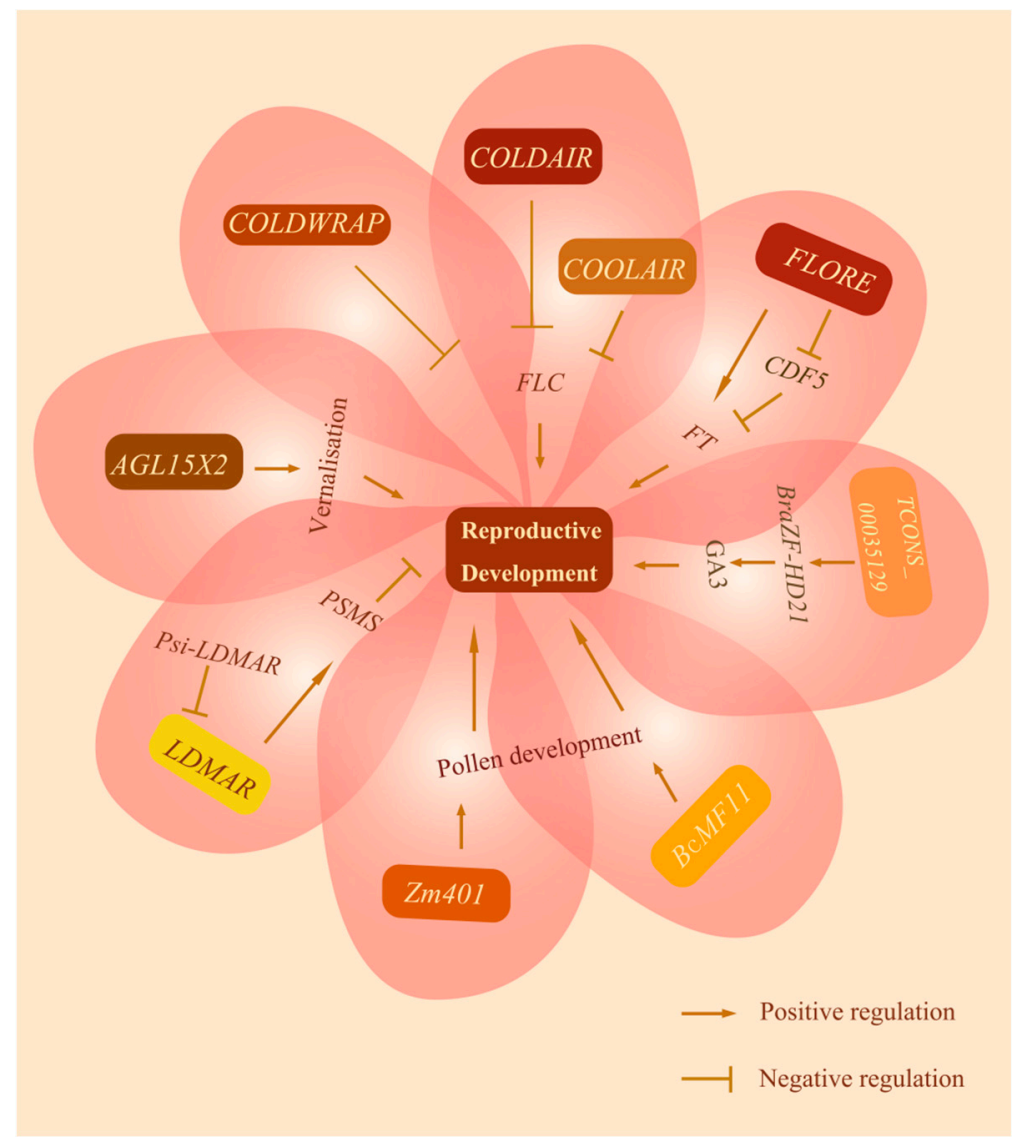

Figure 1. A simplified schematic of lncRNAs identified in plant reproductive development. Cold induced long antisense intragenic RNA (COOLAIR), cold of winter-induced noncoding RNA from the promoter (COLDAIR), and cold of winter-induced noncoding RNA from the promoter (COLDWRAP) can repress the FLOWERING LOCUS C (FLC) gene to stimulate vernalization; CDF5 LONG NONCODING RNA (FLORE), a natural antisense transcript (NAT) of CYCLING DOF FACTOR 5 (CDF5), promotes CDF5 and increases FLOWERING LOCUS T (FT) transcript level; TCONS_00035129 results in changes of hormone content of gibberellin $A_{3}\left(G_{3}\right)$ in vernalized plants by regulating BraZF-HD21 target genes in Brassica rapa; AGLX2 promotes reproductive growth to vernalization; and LDMAR can regulate photoperiodic-sensitive male sterility (PSMS) in rice. The silencing of LDMAR is mediated by Psi-LDMAR through an RNA-dependent DNA methylation (RdDM) pathway; and Zm401 and BcMF11 are involved in regulation of pollen development.

\subsection{Vernalization}

The timing of flowering greatly affects the production of seeds and fruit [87]. Vernalization, an adaptation to avoid pre-winter flowering, contributes significantly to flowering time in accordance with the seasonal changes for biannual and perennial plants in temperate and boreal climates [5]. $F L C$ is key for inhibiting flowering under cold temperatures and is crucial for the vernalization and flowering time control in Arabidopsis thaliana [88]. Before exposure to low temperatures during vernalization, the level of $F L C$ expression is high. High levels of histone H3K4 trimethylation and H3K36 trimethylation are observed, which are regarded as the "active" marks of gene expression. Conversely, the expression of H3K27me3 is low [89] (Figure 2). With winter forthcoming, FLC expression is repressed by autonomous-pathway genes and constitutive $F L C$ repressors [90,91]. Recent studies have shown that non-coding RNAs, such as intronic RNAs [6], antisense lncRNAs [82,92,93], 
and small RNAs [7] are involved in modulation of FLC expression [94]. The first lncRNA involved in the regulation of FLC was called COOLAIR, which is located at the $3^{\prime}$ end of the FLC locus $[95,96]$ and accumulates in the vernalization process [58] (Figure 2). COOLAIR comprises the Class I and II polyadenylated antisense $F L C$ transcripts, and has been proposed to trigger vernalization-mediated FLC silencing [71]. The repression of distal COOLAIR transcription has also been shown to be the signal for recruiting FLOWERING LOCUS D (FLD) to FLC chromatin and leads to H3K4 demethylation [75-77] (Figure 2). However, the regulatory role of COOLAIR in FLC and the vernalization process has yielded controversial results $[97,98]$. Novel findings show that $F T$, an important gene in the control of flowering time, represses the expression of FLC by activating COOLAIR [99], which suggests that the feedback regulation of COOLAIR expression controls flowering time and seeds dormancy. Another lncRNA, COLDAIR, which is 5'-end capped but not polyadenylated and transcribed from the FLC intron 1, has been also found to be involved in vernalization [92]. Transcription of COLDAIR occurs later than that of COOLAIR during vernalization [100]. COLDAIR can recruit PRC2 to stimulate H3K9me2 and H3K27me3 accumulation, thereby silencing the expression of FLC [6,97] (Figure 2). Recent studies showed that cold of winter-induced noncoding RNA from the promoter (COLDWRAP) is generated by an $F L C$-inhibiting promoter and necessary for the stable repressive state of FLC (Figure 2). Taken together, these results indicate that both COLDAIR and COLDWRAP are necessary for vernalization [101]. Notably, after COLDAIR is silenced by RNA interference, plants will maintain a delay of flowering with the onset of spring [6]. Therefore, interactions between lncRNAs and the maintenance of the FLC locus associated with PRC2 warrant further investigation. Subsequently, genome-wide studies using custom-made NAT arrays in A. thaliana identified lncRNA CDF5 LONG NONCODING RNA (FLORE), a NAT of CYCLING DOF FACTOR5 (CDF5) $[61,68,79,102,103]$. CDF5 delays flowering by directly binding to the promoters of CONSTANS (CO) and FT, whereas FLORE promotes the increase of $F T$ transcript levels, indicating that the CDF5/FLORE NAT pair may be a new regulatory mechanism of flowering $[61,68,79,102,103]$. The lncRNA TCONS_00035129 was found to map to the plant hormone signal transduction pathway and to increase the content of plant hormone gibberellin $\mathrm{A}_{3}$, thereby affecting the process of hormone biosynthesis in vernalization [61] (Figure 1). The first candidate IncRNA in sugar beet, AGL15X1, has been shown to be coordinated with the FT target genes BvFT2 and to repress BvFT1, thereby promoting vernalization during cold conditions [103]. 




Figure 2. Schematic illustrations of the regulation of $F L C$ regulated by long noncoding RNAs (lncRNAs) and chromatin modifying complexes during the course of vernalization. (a) Before cold, FLC is actively transcribed by activation complexes, PAF1, which methylates of H3K4me3 and H3K36me3 at high levels and H3K27me3 at a low level; (b) During cold, lncRNAs COLDAIR and COLDWRAP recruit the PRC2 complex to repress $F L C$, which also repressed by COOLAIR, and the methylation of H3K27me3 increases; (c) After cold, FLC is stably silenced by PRC2 complexes, maintaining H3K27me3 through the whole FLC chromatin. As the FLC locus passes to the next generation, the active chromatin state represented in (a) is re-established.

\subsection{Photoperiodic-Sensitive Male Sterility and Pollen Development}

The role of pollen development is significant for plant reproductive development [104]. Research showed that lncRNAs also act as a layer in the regulation network of pollen development, which is a complicated physical-chemical process. After the Nongken $58 S$ mutant was reported to be associated with photoperiodic-sensitive male sterility (PSMS) in plants [105], further genetic analysis showed that a $1236 \mathrm{nt}$ lncRNA, LDMAR, regulated PSMS in rice [106]. LDMAR participates in the regulation of rice fertility under long day conditions [106] (Figure 1). Decreased LDMAR expression may result in premature programmed cell death in immature anthers, and photosensitive male sterility [106]. Other studies have shown that a siRNA produced by LDMAR promoter transcription can induce RNA-directed DNA methylation in the LDMAR promoter region, thereby inhibiting LDMAR expression [79]. Subsequently, LDMAR can be repressed through an RNA-dependent DNA methylation (RdDM) pathway, which is induced by the siRNA Psi-LDMAR [79]. In other species, lncRNAs that regulate pollen development were found, including a stamen-specific expression of lncRNA Zm401 in maize [68]. Zm401 impaired the expression of pollen developmental genes by regulating the key genes Zm3-3, ZmMADS2, and ZmC5. Reducing Zm401 expression will cause male sterility in maize (Figure 1). LncRNA BcMF11 is $828 \mathrm{nt}$, and was identified in Brassica campestris L. spp. 
The lowered expression of BcMF11 will cause pollen grains to be unable to mature [107], suggesting that $B c M F 11$ was specialized to regulate reproductive development [108]. In addition, when BcMF11 was silenced, female flower development was normal, whereas tapetum and microspore development were abnormal, which resulted in male pollen abortion and male sterility [109] (Figure 1). Taken together, these data showed lncRNAs are crucial for the regulation of plant pollen development.

\section{Perspectives}

The functions of lncRNAs in plant reproductive development are investigated continuously and attract increasing research attention. Plant reproductive development is not only one of the most important stages in plant development, but also a crucial process for human life. Therefore, it is important to explore the regulation mechanisms of lncRNAs in plant reproduction $[17,103]$. Here we summarized several types of methods for studying lncRNA regulation in plant reproductive development (Figure 3).

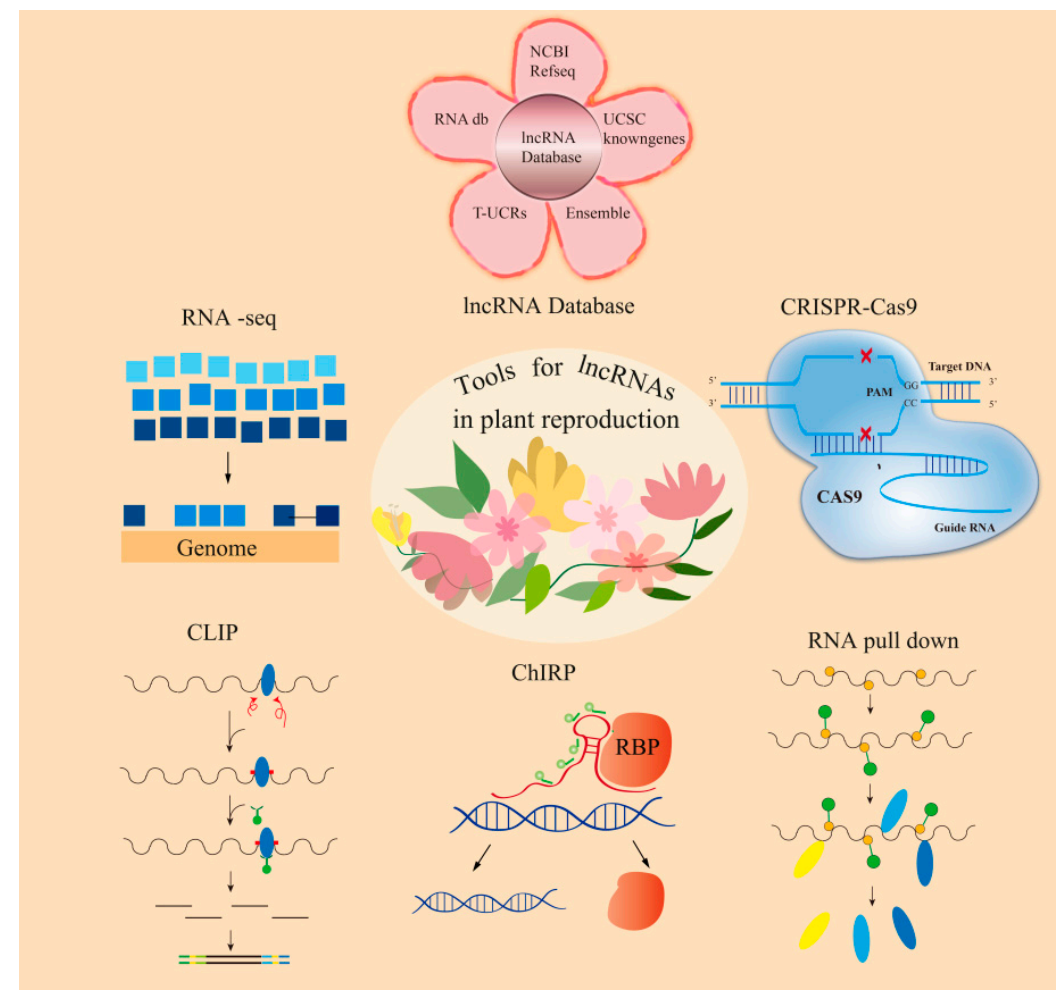

Figure 3. Summary of the current technologies for studying long noncoding RNAs (lncRNAs) in plant reproductive development. LncRNA expression profiles by RNA-seq; screening lncRNAs with different expression by lncRNA databases; silencing lncRNAs for loss-of-function study with methods like clustered regularly interspaced short palindromic repeats (CRISPR)/-associated protein 9 (Cas9); detecting the interaction between lncRNAs and other molecules by RNA pull down, chromatin Isolation by RNA Purification (ChIRP) and crosslinking-immunprecipitation (CLIP).

\subsection{Technical Challenges}

Based on classical methods of lncRNA research, the most important approaches for discovery, prediction, and identification of IncRNAs include microarrays, RNA sequencing, fluorescence in situ hybridization (FISH), and RNA interference (RNAi). The future development of plant lncRNA identification will be largely dependent on the optimization of high-throughput sequencing technology. For example, the paired-end strand-specific RNA sequencing can provide transcript information more accurately in the future, suggesting that the expression of lncRNAs during plant reproductive development will be shown in more detail [110]. In the future, the functions of identified lncRNAs 
and data sets of lncRNAs in plant reproductive development need to be updated and made available in databases, such as NCBI-Gene, Ensembl, NONCODE, and LNCipedia [71,111], which at present mainly focus on human diseases and animal cells. Furthermore, new predictive tools which can analyze sequences, chromosome location, and time/tissue specificity of lncRNAs in plants, particularly during reproductive development, are urgently needed. Because of the numerous differences between biological functions of IncRNAs inside and outside the nucleus, more accurate and appropriate cellular localization techniques are needed for the further functional study of lncRNAs identified by high-throughput sequencing. Traditionally, validation of plant lncRNA localization has been performed using FISH, which has been a bottleneck in the study of heterogeneity and subcellular localization of plant RNA molecules in single cells due to the particularity of samples and the limitation of auto fluorescence in vivo.

To address these problems, single-molecule RNA FISH (smFISH) was introduced to visualize individual RNAs using multiple fluorescently labeled oligonucleotide probes specific to the target RNA [112]. SmFISH enables direct quantitation of mRNA, and multiple RNA species can be scored simultaneously in the same cell by multiplexing smFISH probes [113]. It has been applied for subcellular localization of COOLAIR at a cellular level [114]. Using the Stellaris smFISH technique, FLC and its antisense transcript, COOLAIR, did not appear in the same cell in most cases during cold exposure, and their localizations in cells seemed mutually exclusive. The application of smFISH with COOLAIR is likely to reveal that the sense transcription and antisense transcription of FLC are mutually exclusive at the spatialization level and will provide insights into the regulation function of COOLAIR in vernalization of plants. Furthermore, this approach will help to establish a technique to detect the localization and quantification of a single RNA in Arabidopsis thaliana [114]. This method can be widely applied to other plants by optimization of the sample processing in order to overcome spontaneous fluorescence in plant green tissues. Considering the multitude of applications in model organisms [115], we believe that smFISH will become a new powerful tool for lncRNA research in plant reproduction.

In order to investigate the functions of lncRNAs, clustered regularly interspaced short palindromic repeats (CRISPR)/-associated protein 9 (Cas9)-induced genome editing technology has been an efficient and powerful tool [116]. Relying on relatively low abundances of off-target sites after knockout of the target gene, the efficiency of DNA disruption, and the inheritance of function fails, CRISPR/Cas9-induced genome editing technology has been considered appropriate to lncRNA loss-of-function analysis [117]. In order to investigate the gene function, the CRISPR/Cas9 system has been successfully applied to create multisite genome knockout mutations. Compared with wild-type fruits, the CRISPR/Cas9-engineered lncRNA1459 mutations showed significant delays of ripening in Solanum lycopersicum [118,119], suggesting that CRISPR/Cas9 technology is a potential avenue for research on lncRNAs involved in the regulation of plant reproductive development $[120,121]$. Although Cas9 has proven its utility in loss-off-function studies, there is some controversy as a knocked-out DNA molecule may still participate in regulating the transcription of neighboring mRNAs [122]. Generally, the lncRNA functional analysis in plant reproductive development is full of challenges and uncertainties, and therefore the use of newly developed technologies and methods is recommended to benefit from progress made in other fields of research.

\subsection{Strategies}

In recent years, due to the increasing availability and rapid development of high-throughput transcriptome profiling techniques, an increasing number of lncRNAs of various plant species have been reported. Although the studies on regulation mechanisms of lncRNA were shown to be difficult, we present several avenues for illuminating the regulation mechanism of lncRNAs according to the regulation levels of lncRNA, including post-transcriptional regulation, epigenetic modification, and transcriptional regulation. 
In the cytoplasm, ceRNAs, which regulate other RNA transcripts by competing for shared miRNAs, are an emerging model of post-transcriptional regulation [77]. Recent studies have found that lncRNAs can act as "sponges" of miRNAs and bind to miRNAs competitively, preventing the inhibition of target genes by miRNAs $[77,123]$. If localized in the cytoplasm, a binding miRNA shared by lncRNA and mRNA may occur, which necessitates experiments to test the regulatory relationship between these molecules [124]. However, the ceRNA regulation research is at an early stage in plants, particularly compared with its state in cancer research [3,125-127]. As the first ceRNA was identified in a process of germination in rice, future analysis will need to focus on the regulation mechanisms of ceRNA in plant reproductive development.

If an IncRNA is localized within the nucleus, its potential regulatory role at the chromatin level should be considered. The main research foci to test the hypothesis are: (i) To determine whether IncRNA binds to chromatin; (ii) whether chromatin status is affected by IncRNA; (iii) to identify the locations of specific regulatory regions; (iv) to identify the lncRNA binding proteins; and (v) whether the expression of target genes is affected by lncRNA. LncRNA can also act as a transcriptional coactivator in the nucleus at the transcriptional regulation level. Studies have found that lncRNAs act in cis to regulate the expression of nearby mRNAs. In this case, it is necessary to confirm whether there is an expression correlation of the lncRNA and target genes, and whether the expression of mRNA is affected by the intervention of IncRNA. In addition, follow-up studies are needed to examine whether IncRNAs recruit proteins or complexes to later bind to gene promoter regions in order to achieve regulatory functions [128-130]. In contrast, if IncRNAs exert trans-regulatory functions, RNA pulldown screening can be used to find lncRNA binding proteins (Figure 3) [6]. For this, it is necessary to first identify the proteins that may bind to lncRNAs, or to find the downstream targets, and second, to analyze the correlation between the expression of the lncRNA and target genes. Finally, it needs to be demonstrated whether the lncRNA and the binding proteins bind to the promoter region of the target gene for expression regulation.

Although many lncRNAs can be identified during flowering and other phases of plant development at the present, our knowledge of the functions and regulation mechanisms of lncRNAs is still limited. Although our knowledge of lncRNA-mediated regulation of vernalization is steadily increasing the understanding of the regulatory mechanisms of lncRNAs, substantial progress in this field is still to be made. The era of determining the function of plant lncRNAs is just beginning. How to map the biological functions and the mechanism of regulation of lncRNAs from animals and diseases to plant reproductive development and how to establish a better prediction and verification of lncRNA in plant reproductive development are extremely difficult. The rapid advancement of technologies will bring new opportunities and breakthroughs in lncRNA research, and the unexplored fields of plant reproductive development will gradually be explored.

Author Contributions: T.Y. and H.Z. wrote the manuscript.

Funding: This work was funded by the National Natural Science Foundation of China, grant no. 31622050, 91540118, and 31672208 .

Acknowledgments: We wish to thank Tian Wang, Yongfang Yang, Ran Li, Xindi Li and Guoning Zhu for critical review of the manuscript.

Conflicts of Interest: The authors declare no conflict of interest.

\section{References}

1. Turck, F.; Fornara, F.; Coupland, G. Regulation and identity of florigen: FLOWERING LOCUS T moves center stage. Annu. Rev. Plant Biol. 2008, 59, 573-594. [CrossRef]

2. Wilkie, J.D.; Sedgley, M.; Olesen, T. Regulation of floral initiation in horticultural trees. J. Exp. Bot. 2008, 59, 3215-3228. [CrossRef]

3. Cui, H.; Onyango, P.; Brandenburg, S.; Wu, Y.; Hsieh, C.L.; Feinberg, A.P. Loss of Imprinting in Colorectal Cancer Linked to Hypomethylation of H19 and IGF2. Cancer Res. 2002, 62, 6442-6446. [PubMed] 
4. Ausín, I.; Alonso-Blanco, C.; Martínez-Zapater, J.M. Environmental regulation of flowering. Int. J. Dev. Boil. 2004, 49, 689-705. [CrossRef]

5. Amasino, R.M. Vernalization and flowering time. Curr. Opin. Biotechnol. 2005, 16, 154-158. [CrossRef] [PubMed]

6. Heo, J.B.; Sung, S. Vernalization-mediated epigenetic silencing by a long intronic noncoding RNA. Science 2011, 331, 76-79. [CrossRef] [PubMed]

7. Swiezewski, S.; Crevillen, P.; Liu, F.; Ecker, J.R.; Jerzmanowski, A.; Dean, C. Small RNA-Mediated Chromatin Silencing Directed to the $3^{\prime}$ Region of the Arabidopsis Gene Encoding the Developmental Regulator, FLC. Proc. Natl. Acad. Sci. USA 2007, 104, 3633-3638. [CrossRef] [PubMed]

8. Amor, B.B.; Wirth, S.; Merchan, F.; Laporte, P.; D’Aubenton-Carafa, Y.; Hirsch, J.; Maizel, A.; Mallory, A.; Lucas, A.; Deragon, J.M. Novel long non-protein coding RNAs involved in Arabidopsis differentiation and stress responses. Genome Res. 2009, 19, 57-69. [CrossRef]

9. Bai, Y.; Dai, X.; Harrison, A.P.; Chen, M. RNA regulatory networks in animals and plants: A long noncoding RNA perspective. Brief. Funct. Genom. 2015, 14, 91-101. [CrossRef]

10. Zhang, J.; Cui, X.W.; Shen, Y.H.; Pang, L.X.; Zhang, A.Q.; Fu, Z.Y.; Chen, J.T.; Guo, X.R.; Gan, W.H.; Ji, C.B. Distinct expression profiles of LncRNAs between brown adipose tissue and skeletal muscle. Biochem. Biophys. Res. Commun. 2014, 443, 1028-1034. [CrossRef]

11. Yuen-Yi, T.; Moriarity, B.S.; Wuming, G.; Ryutaro, A.; Ashutosh, T.; Hiroko, K.; Peter, R.; Brian, R.; Kacey, G.; Beadnell, T.C. PVT1 dependence in cancer with MYC copy-number increase. Nature 2014, 512, 82-86.

12. Wang, Y.; He, L.; Du, Y.; Zhu, P.; Huang, G.; Luo, J.; Yan, X.; Ye, B.; Li, C.; Xia, P. The long noncoding RNA lncTCF7 promotes self-renewal of human liver cancer stem cells through activation of Wnt signaling. Cell Stem Cell 2015, 16, 413-425. [CrossRef] [PubMed]

13. Mchugh, C.A.; Chun-Kan, C.; Amy, C.; Surka, C.F.; Christina, T.; Patrick, M.D.; Amy, P.J.; Mario, B.; Christina, B.; Annie, M. The Xist lncRNA interacts directly with SHARP to silence transcription through HDAC3. Nature 2015, 521, 232-236. [CrossRef] [PubMed]

14. Jiang, C.; Xin, L.; Hui, Z.; Liu, H. Long non-coding RNAs: Potential new biomarkers for predicting tumor invasion and metastasis. Mol. Cancer 2016, 15, 62. [CrossRef]

15. Lossos, I.S.; Morgensztern, D. Prognostic Biomarkers in Diffuse Large B-Cell Lymphoma. J. Clin. Oncol. 2006, 24, 995-1007. [CrossRef]

16. Zhou, M.; Zhao, H.; Xu, W.; Bao, S.; Liang, C.; Sun, J. Discovery and validation of immune-associated long non-coding RNA biomarkers associated with clinically molecular subtype and prognosis in diffuse large B cell lymphoma. Mol. Cancer 2017, 16, 16. [CrossRef]

17. Ariel, F.; Romerobarrios, N.; Jégu, T.; Benhamed, M.; Crespi, M. Battles and hijacks: Noncoding transcription in plants. Trends Plant Sci. 2015, 20, 362-371. [CrossRef]

18. Bazin, J.; Baileyserres, J. Emerging roles of long non-coding RNA in root developmental plasticity and regulation of phosphate homeostasis. Front. Plant Sci. 2015, 6, 400. [CrossRef]

19. Shafiq, S.; Li, J.; Sun, Q. Functions of plants long non-coding RNAs. BBA Gene Regul. Mech. 2016, 1859, 155-162. [CrossRef]

20. Zhu, Q.H.; Wang, M.B. Molecular Functions of Long Non-Coding RNAs in Plants. Genes 2012, 3, $176-190$. [CrossRef]

21. Zhang, Y.C.; Chen, Y.Q. Long noncoding RNAs: New regulators in plant development. Biochem. Biophys. Res. Commun. 2013, 436, 111-114. [CrossRef] [PubMed]

22. Wang, X.J.; Gaasterland, T.; Chua, N.H. Genome-wide prediction and identification of cis-natural antisense transcripts in Arabidopsis thaliana. Genome Biol. 2005, 6. [CrossRef]

23. Wang, H.; Chua, N.-H.; Wang, X.-J. Prediction of trans-antisense transcripts in Arabidopsis thaliana. Genome Biol. 2006, 7. [CrossRef]

24. Song, D.; Yang, Y.; Yu, B.; Zheng, B.; Deng, Z.; Lu, B.-L.; Chen, X.; Jiang, T. Computational prediction of novel non-coding RNAs in Arabidopsis thaliana. BMC Bioinform. 2009, 10. [CrossRef] [PubMed]

25. Hotto, A.M.; Schmitz, R.J.; Fei, Z.; Ecker, J.R.; Stern, D.B. Unexpected Diversity of Chloroplast Noncoding RNAs as Revealed by Deep Sequencing of the Arabidopsis Transcriptome. G3 2011, 1, 559-570. [CrossRef] [PubMed] 
26. Jun, L.; Choonkyun, J.; Jun, X.; Huan, W.; Shulin, D.; Lucia, B.; Catalina, A.H.; Nam-Hai, C. Genome-wide analysis uncovers regulation of long intergenic noncoding RNAs in Arabidopsis. Plant Cell 2012, 24, 4333-4345.

27. Li, S.; Liberman, L.M.; Mukherjee, N.; Benfey, P.N.; Ohler, U. Integrated detection of natural antisense transcripts using strand-specific RNA sequencing data. Genome Res. 2013, 23, 1730-1739. [CrossRef] [PubMed]

28. Wang, Y.; Wang, X.; Deng, W.; Fan, X.; Liu, T.-T.; He, G.; Chen, R.; Terzaghi, W.; Zhu, D.; Deng, X.W. Genomic Features and Regulatory Roles of Intermediate-Sized Non-Coding RNAs in Arabidopsis. Mol. Plant 2014, 7, 514-527. [CrossRef]

29. Wang, H.; Chung, P.J.; Liu, J.; Jang, I.-C.; Kean, M.J.; Xu, J.; Chua, N.-H. Genome-wide identification of long noncoding natural antisense transcripts and their responses to light in Arabidopsis. Genome Res. 2014, 24, 444-453. [CrossRef]

30. Di, C.; Yuan, J.; Wu, Y.; Li, J.; Lin, H.; Hu, L.; Zhang, T.; Qi, Y.; Gerstein, M.B.; Guo, Y.; et al. Characterization of stress-responsive lncRNAs in Arabidopsis thaliana by integrating expression, epigenetic and structural features. Plant J. 2014, 80, 848-861. [CrossRef]

31. Osato, N.; Yamada, H.; Satoh, K.; Ooka, H.; Yamamoto, M.; Suzuki, K.; Kawai, J.; Carninci, P.; Ohtomo, Y.; Murakami, K.; et al. Antisense transcripts with rice full-length cDNAs. Genome Biol. 2003, 5, R5. [CrossRef] [PubMed]

32. Markov, A.G.; Falchuk, E.L.; Kruglova, N.M.; Rybalchenko, O.V.; Fromm, M.; Amasheh, S. Genome-wide identification and analysis of small RNAs originated from natural antisense transcripts in Oryza sativa. Genome Res. 2009, 19, 70-78.

33. Lu, T.; Zhu, C.; Lu, G.; Guo, Y.; Zhou, Y.; Zhang, Z.; Zhao, Y.; Li, W.; Lu, Y.; Tang, W. Strand-specific RNA-seq reveals widespread occurrence of novel cis- natural antisense transcripts in rice. BMC Genomics 2012, $13,721$. [CrossRef] [PubMed]

34. Zhang, Y.C.; Liao, J.Y.; Li, Z.Y.; Yu, Y.; Zhang, J.P.; Li, Q.F.; Qu, L.H.; Shu, W.S.; Chen, Y.Q. Genome-wide screening and functional analysis identify a large number of long noncoding RNAs involved in the sexual reproduction of rice. Genome Biol. 2014, 15, 512. [CrossRef] [PubMed]

35. Boerner, S.; McGinnis, K.M. Computational Identification and Functional Predictions of Long Noncoding RNA in Zea mays. PLoS ONE 2012, 7. [CrossRef] [PubMed]

36. Li, L.; Eichten, S.R.; Shimizu, R.; Petsch, K.; Yeh, C.-T.; Wu, W.; Chettoor, A.M.; Givan, S.A.; Cole, R.A.; Fowler, J.E.; et al. Genome-wide discovery and characterization of maize long non-coding RNAs (vol 15, R40, 2014). Genome Biol. 2018, 19. [CrossRef] [PubMed]

37. Zhang, W.; Han, Z.; Guo, Q.; Liu, Y.; Zheng, Y.; Wu, F.; Jin, W. Identification of Maize Long Non-Coding RNAs Responsive to Drought Stress. PLoS ONE 2014, 9. [CrossRef] [PubMed]

38. Xin, M.; Wang, Y.; Yao, Y.; Song, N.; Hu, Z.; Qin, D.; Xie, C.; Peng, H.; Ni, Z.; Sun, Q. Identification and characterization of wheat long non-protein coding RNAs responsive to powdery mildew infection and heat stress by using microarray analysis and SBS sequencing. BMC Plant Biol. 2011, 11. [CrossRef]

39. Lu, X.; Chen, X.; Mu, M.; Wang, J.; Wang, X.; Wang, D.; Yin, Z.; Fan, W.; Wang, S.; Guo, L. Genome-wide analysis of long noncoding rnas and their responses to drought stress in cotton (Gossypium hirsutum L.). PLOS ONE 2016, 11, e0156723.

40. Zou, C.; Wang, Q.; Lu, C.; Yang, W.; Zhang, Y.; Cheng, H.; Feng, X.; Prosper, M.A.; Song, G. Transcriptome analysis reveals long noncoding RNAs involved in fiber development in cotton (Gossypium arboreum). Sci. China-Life Sci. 2016, 59, 164-171. [CrossRef] [PubMed]

41. Shuai, P.; Liang, D.; Tang, S.; Zhang, Z.; Ye, C.-Y.; Su, Y.; Xia, X.; Yin, W. Genome-wide identification and functional prediction of novel and drought-responsive lincRNAs in Populus trichocarpa. J. Exp. Bot. 2014, 65, 4975-4983. [CrossRef]

42. Celton, J.M.; Gaillard, S.; Bruneau, M.; Pelletier, S.; Aubourg, S.; Martin-Magniette, M.L.; Navarro, L.; Laurens, F.; Renou, J.P. Widespread anti-sense transcription in apple is correlated with siRNA production and indicates a large potential for transcriptional and/or post-transcriptional control. New Phytol. 2014, 203, 287-299. [CrossRef]

43. Wen, J.; Parker, B.J.; Weiller, G.F. In silico identification and characterization of mRNA-Like Noncoding transcripts in Medicago truncatula. In Silico Biol. 2007, 7, 485-505. [PubMed] 
44. Wang, J.; Jing, L.; Kan, J.; Hong, W.; Li, X.; Yang, Q.; Hui, L.; Chang, Y. Genome-Wide Identification and Functional Prediction of Novel Drought-Responsive lncRNAs inPyrus betulifolia. Genes 2018, 9, 311. [CrossRef] [PubMed]

45. Wang, L.; Zhao, S.; Gu, C.; Zhou, Y.; Zhou, H. Deep RNA-Seq uncovers the peach transcriptome landscape. Plant Mol. Biol. 2013, 83, 365-377. [CrossRef] [PubMed]

46. Yu, X.; Yang, J.; Li, X.; Liu, X.; Sun, C.; Wu, F.; He, Y. Global analysis of cis-natural antisense transcripts and their heat-responsive nat-siRNAs in Brassica rapa. BMC Plant Biol. 2013, 13, 208. [CrossRef] [PubMed]

47. Tang, W.; Zheng, Y.; Dong, J.; Yu, J.; Yue, J.; Liu, F.; Guo, X.; Huang, S.; Wisniewski, M.; Sun, J.; et al. Comprehensive transcriptome profiling reveals long noncoding rna expression and alternative splicing regulation during fruit development and ripening in kiwifruit (Actinidia chinensis). Front. Plant Sci. 2016, 7. [CrossRef]

48. Hao, Z.; Fan, C.; Cheng, T.; Su, Y.; Wei, Q.; Li, G. Genome-Wide Identification, Characterization and Evolutionary Analysis of Long Intergenic Noncoding RNAs in Cucumber. PLoS ONE 2015, 10. [CrossRef]

49. Flórez-Zapata, N.M.V.; Reyes-Valdés, M.H.; Martínez, O. Long non-coding RNAs are major contributors to transcriptome changes in sunflower meiocytes with different recombination rates. BMC Genomics 2016, 17, 490. [CrossRef]

50. Zhu, Y.; Chen, L.; Zhang, C.; Hao, P.; Jing, X.; Li, X. Global transcriptome analysis reveals extensive gene remodeling, alternative splicing and differential transcription profiles in non-seed vascular plant Selaginella moellendorffii. BMC Genomics 2017, 18, 1042. [CrossRef]

51. Zhang, G.; Duan, A.; Zhang, J.; He, C. Genome-wide analysis of long non-coding RNAs at the mature stage of sea buckthorn (Hippophae rhamnoides Linn) fruit. Gene 2017, 596, 130-136. [CrossRef] [PubMed]

52. Zhu, B.; Yang, Y.; Li, R.; Fu, D.; Wen, L.; Luo, Y.; Zhu, H. RNA sequencing and functional analysis implicate the regulatory role of long non-coding RNAs in tomato fruit ripening. J. Exp. Bot. 2015, 66, 4483-4495. [CrossRef] [PubMed]

53. Shoemaker, D.D.; Schadt, E.E.; Armour, C.D.; He, Y.D.; Garrettengele, P.; Mcdonagh, P.D.; Loerch, P.M.; Leonardson, A.; Lum, P.Y.; Cavet, G. Experimental annotation of the human genome using microarray technology. Nature 2001, 409, 922-927. [CrossRef]

54. Zhang, M.; Zhao, H.; Xie, S.; Chen, J.; Xu, Y.; Wang, K.; Zhao, H.; Guan, H.; Hu, X.; Jiao, Y. Extensive, clustered parental imprinting of protein-coding and noncoding RNAs in developing maize endosperm. Proc. Natl. Acad. Sci. USA 2011, 108, 20042-20047. [CrossRef]

55. Zhu, Q.H.; Stephen, S.; Taylor, J.; Helliwell, C.A.; Wang, M.B. Long noncoding RNAs responsive to Fusarium oxysporum infection in Arabidopsis thaliana. New Phytol. 2014, 201, 574-584. [CrossRef] [PubMed]

56. Chao, D.; Jiapei, Y.; Yue, W.; Jingrui, L.; Huixin, L.; Long, H.; Ting, Z.; Yijun, Q.; Gerstein, M.B.; Yan, G. Characterization of stress-responsive lncRNAs in Arabidopsis thaliana by integrating expression, epigenetic and structural features. Plant J. 2015, 80, 848-861.

57. Wang, H.; Niu, Q.W.; Wu, H.W.; Liu, J.; Ye, J.; Yu, N.; Chua, N.H. Analysis of noncoding transcriptome in rice and maize uncovers roles of conserved lncRNAs associated with agriculture traits. Plant J. 2015, 84, 404-416. [CrossRef] [PubMed]

58. Carbonell, P.; Rodriguezescudero, A.I. The Solanum commersonii Genome Sequence Provides Insights into Adaptation to Stress Conditions and Genome Evolution of Wild Potato Relatives. Plant Cell 2015, 27, 954-968.

59. Liu, S.; Sun, Z.; Xu, M. Identification and characterization of long non-coding RNAs involved in the formation and development of poplar adventitious roots. Ind. Crops Prod. 2018, 118, 334-346. [CrossRef]

60. Kiegle, E.A.; Garden, A.; Lacchini, E.; Kater, M.M. A Genomic View of Alternative Splicing of Long Non-coding RNAs during Rice Seed Development Reveals Extensive Splicing and lncRNA Gene Families. Front. Plant Sci. 2018, 9, 115. [CrossRef] [PubMed]

61. Liu, T.; Wu, P.; Wang, Q.; Wang, W.; Zhang, C.; Sun, F.; Liu, Z.; Li, Y.; Hou, X. Comparative transcriptome discovery and elucidation of the mechanism of long noncoding RNAs during vernalization in Brassica rapa. Plant Growth Regul. 2018, 85, 27-39. [CrossRef]

62. Yu, T.; Tzeng, D.; Li, R.; Chen, J.; Zhong, S.; Fu, D.; Zhu, B.; Luo, Y.; Zhu, H. Genome-wide identification of long non-coding RNA targets of the tomato MADS box transcription factor RIN and function analysis. Ann. Bot. 2018. [CrossRef] [PubMed]

63. Juan, W.; Toshihiro, O.; Toru, F.; Takahiko, T.; Masahiro, S.; Yasushi, Y. A novel hypoxic stress-responsive long non-coding RNA transcribed by RNA polymerase III in Arabidopsis. RNA Boil. 2012, 9, 302-313. 
64. Cho, J.; Koo, D.H.; Nam, Y.W.; Han, C.T.; Lim, H.T.; Bang, J.W.; Hur, Y. Isolation and characterization of cDNA clones expressed under male sex expression conditions in a monoecious cucumber plant (Cucumis sativus $\mathrm{L}$. cv. Winter Long). Euphytica 2006, 146, 271-281. [CrossRef]

65. Markus, W.; Rita, G.H.; Friedrich, S.F. Heat shock factor HSFB2a involved in gametophyte development of Arabidopsis thaliana and its expression is controlled by a heat-inducible long non-coding antisense RNA. Plant Mol. Boil. 2014, 85, 541-550.

66. Miao-Chih, T.; Ohad, M.; Yue, W.; Nima, M.; Wang, J.K.; Fei, L.; Yang, S.; Eran, S.; Chang, H.Y. Long noncoding RNA as modular scaffold of histone modification complexes. Science 2010, 329, 689-693.

67. Nakamoto, S.; Tashiro, K.; Matsumoto, A. Rice ENOD40: Isolation and expression analysis in rice and transgenic soybean root nodules. Plant J. 2010, 18, 121-129.

68. Dai, X.Y.; Yu, J.J.; Zhao, Q.; Zhu, D.Y.; Ao, G.M. Non-coding RNA for ZM401, a pollen-specific gene of Zea mays. Acta Bot. Sin. 2004, 46, 497-504.

69. Jack, T. Molecular and Genetic Mechanisms of Floral Control. Plant Cell 2004, 16, S1-S17. [CrossRef]

70. Filipe, B.; Martienssen, R.A. The expanding world of small RNAs in plants. Nat. Rev. Mol. Cell Boil. 2015, 16, 727-741.

71. Zhao, J.; Liu, Y.; Huang, G.; Cui, P.; Zhang, W.; Zhang, Y. Long non-coding RNAs in gastric cancer: Versatile mechanisms and potential for clinical translation. Am. J. Cancer Res. 2015, 5, 907-927.

72. Wang, P.; Xu, J.; Wang, Y.; Cao, X. An interferon-independent lncRNA promotes viral replication by modulating cellular metabolism. Science 2017, 358, 1051-1055. [CrossRef] [PubMed]

73. Jiang, M.; Zhang, S.; Yang, Z.; Lin, H.; Zhu, J.; Liu, L.; Wang, W.; Liu, S.; Liu, W.; Ma, Y. Self-Recognition of an Inducible Host lncRNA by RIG-I Feedback Restricts Innate Immune Response. Cell 2018, 173, 906-919. [CrossRef] [PubMed]

74. Wang, K.C.; Chang, H.Y. Molecular mechanisms of long noncoding RNAs. Mol. Cell 2011, 43, 904-914. [CrossRef] [PubMed]

75. Wu, H.J.; Wang, Z.M.; Wang, M.; Wang, X.J. Widespread long noncoding RNAs as endogenous target mimics for microRNAs in plants. Plant Physiol. 2013, 161, 1875-1884. [CrossRef] [PubMed]

76. Franco-Zorrilla, J.M.; Valli, A.; Todesco, M.; Mateos, I.; Puga, M.I.; Rubio-Somoza, I.; Leyva, A.; Weigel, D.; Garcia, J.A.; Paz-Ares, J. Target mimicry provides a new mechanism for regulation of microRNA activity. Nat. Genet. 2007, 39, 1033-1037. [CrossRef]

77. Salmena, L.; Poliseno, L.; Tay, Y.; Kats, L.; Pandolfi, P.P. A ceRNA hypothesis: The Rosetta Stone of a hidden RNA language? Cell 2011, 146, 353-358. [CrossRef]

78. Yvonne, T.; Lev, K.; Leonardo, S.; Dror, W.; Mynn, T.S.; Ugo, A.; Florian, K.; Laura, P.; Paolo, P.; Ferdinando, D.C. Coding-independent regulation of the tumor suppressor PTEN by competing endogenous mRNAs. Cell 2011, 147, 344-357.

79. Ding, J.; Shen, J.; Mao, H.; Xie, W.; Li, X.; Zhang, Q. RNA-directed dna methylation is involved in regulating photoperiod-sensitive male sterility in rice. Mol. Plant 2012, 5, 1210-1216. [CrossRef]

80. Zhou, H.; Liu, Q.; Li, J.; Jiang, D.; Zhou, L.; Wu, P.; Lu, S.; Li, F.; Zhu, L.; Liu, Z. Photoperiod- and thermo-sensitive genic male sterility in rice are caused by a point mutation in a novel noncoding RNA that produces a small RNA. Cell Res. 2012, 22, 649-660. [CrossRef]

81. Komiya, R.; Ohyanagi, H.; Niihama, M.; Watanabe, T.; Nakano, M.; Kurata, N.; Nonomura, K. Rice germline-specific Argonaute MEL1 protein binds to phasiRNAs generated from more than 700 lincRNAs. Plant J. 2014, 78, 385-397. [CrossRef] [PubMed]

82. Swiezewski, S.; Liu, F.; Magusin, A.; Dean, C. Cold-induced silencing by long antisense transcripts of an Arabidopsis Polycomb target. Nature 2009, 462, 799-802. [CrossRef]

83. Jing, Z.; Bryan, K.S.; Jennifer, A.E.; Ji-Joon, S.; Jeannie, T.L. Polycomb proteins targeted by a short repeat RNA to the mouse X chromosome. Science 2008, 322, 750-756.

84. Lipshitz, H.D.; Peattie, D.A.; Hogness, D.S. Novel transcripts from the Ultrabithorax domain of the bithorax complex. Genes Dev. 1987, 1, 307-322. [CrossRef] [PubMed]

85. Qi, X.; Xie, S.; Liu, Y.; Yi, F.; Yu, J. Genome-wide annotation of genes and noncoding RNAs of foxtail millet in;response to simulated drought stress by deep sequencing. Plant Mol. Boil. 2013, 83, 459-473. [CrossRef] [PubMed]

86. Song, Y.; Ci, D.; Tian, M.; Zhang, D. Stable methylation of a non-coding RNA gene regulates gene expression in response to abiotic stress in Populus simonii. J. Exp. Bot. 2015, 67, 1477-1492. [CrossRef] 
87. Ietswaart, R.; Wu, Z.; Dean, C. Flowering time control: Another window to the connection between antisense RNA and chromatin. Trends Genet. 2012, 28, 445-453. [CrossRef] [PubMed]

88. Helliwell, C.A.; Wood, C.C.; Robertson, M.; James, P.W.; Dennis, E.S. The Arabidopsis FLC protein interacts directly in vivo with SOC1 and FT chromatin and is part of a high-molecular-weight protein complex. Plant J. 2006, 46, 183-192. [CrossRef] [PubMed]

89. He, Y. Control of the Transition to Flowering by Chromatin Modifications. Mol. Plant 2009, 2, 554-564. [CrossRef] [PubMed]

90. Richard, A. Seasonal and developmental timing of flowering. Plant J. 2010, 61, 1001-1013.

91. Johanson, U.; West, J.; Lister, C.; Michaels, S.; Amasino, R.; Dean, C. Molecular analysis of FRIGIDA, a major determinant of natural variation in Arabidopsis flowering time. Science 2000, 290, 344-347. [CrossRef] [PubMed]

92. Csorba, T.; Questa, J.I.; Sun, Q.; Dean, C. Antisense COOLAIR mediates the coordinated switching of chromatin states at FLC during vernalization. Proc. Natl. Acad. Sci. USA 2014, 111, 16160-16165. [CrossRef] [PubMed]

93. Sun, Q.; Csorba, T.; Skourtistathaki, K.; Proudfoot, N.J.; Dean, C. R-Loop Stabilization Represses Antisense Transcription at the Arabidopsis FLC Locus. Science 2013, 340, 619-621. [CrossRef]

94. Sheldon, C.C.; Rouse, D.T.; Finnegan, E.J.; Peacock, W.J.; Dennis, E.S. The molecular basis of vernalization: The central role of FLOWERING LOCUS C (FLC). Proc. Natl. Acad. Sci. USA 2000, 97, 3753-3758. [CrossRef] [PubMed]

95. Yamada, K.; Lim, J.; Dale, J.M.; Chen, H.; Shinn, P.; Palm, C.J.; Southwick, A.M.; Wu, H.C. Empirical analysis of transcriptional activity in the Arabidopsis genome. Science 2003, 302, 842-846. [CrossRef]

96. Rinn, J.L.; Kertesz, M.; Wang, J.K.; Squazzo, S.L.; Xu, X.; Brugmann, S.A.; Goodnough, L.H.; Helms, J.A.; Farnham, P.J.; Segal, E. Functional demarcation of active and silent chromatin domains in human HOX loci by noncoding RNAs. Cell 2007, 129, 1311-1323. [CrossRef]

97. Helliwell, C.A.; Masumi, R.; Jean, F.E.; Buzas, D.M.; Dennis, E.S. Vernalization-Repression of Arabidopsis FLC Requires Promoter Sequences but Not Antisense Transcripts. PLoS ONE 2011, 6, 240-247. [CrossRef] [PubMed]

98. Crevillén, P.; Yang, H.; Cui, X.; Greeff, C.; Trick, M.; Qiu, Q.; Cao, X.; Dean, C. Epigenetic reprogramming that prevents transgenerational inheritance of the vernalized state. Nature 2014, 515, 587-590. [CrossRef] [PubMed]

99. Chen, M.; Penfield, S. Feedback regulation of COOLAIR expression controls seed dormancy and flowering time. Science 2018, 360, 1014-1017. [CrossRef]

100. Michaels, S.D.; Amasino, R.M. FLOWERING LOCUS C encodes a novel MADS domain protein that acts as a repressor of flowering. Plant Cell 1999, 11, 949-956. [CrossRef]

101. Kim, D.H.; Sung, S. Vernalization-Triggered Intragenic Chromatin Loop Formation by Long Noncoding RNAs. Dev. Cell 2017, 40, 302-312. [CrossRef] [PubMed]

102. Henriques, R.; Wang, H.; Liu, J.; Boix, M.; Huang, L.F.; Chua, N.H. The antiphasic regulatory module comprising CDF5 and its antisense RNA FLORE links the circadian clock to photoperiodic flowering. New Phytol. 2017, 216, 854-867. [CrossRef] [PubMed]

103. Liang, N.; Cheng, D.; Cui, J.; Dai, C.; Luo, C.; Liu, T.; Li, J. Vernalisation mediated LncRNA-like gene expression in Beta vulgaris. Funct. Plant Boil. 2017, 44, 720-726. [CrossRef]

104. Loraine, A.E.; Mccormick, S.; Estrada, A.; Patel, K.; Peng, Q. RNA-Seq of Arabidopsis Pollen Uncovers Novel Transcription and Alternative Splicing. Plant Physiol. 2013, 162, 1092-1109. [CrossRef] [PubMed]

105. Liang, M.Z.; Ou, L.J.; Deng, L.X.; Luan, S.; Chen, L.B. Fertility response to photoperiod and temperature in indica photoperiod-sensitive male sterile rice. Russ. J. Plant Physiol. 2008, 55, 694-698. [CrossRef]

106. Ding, J.; Lu, Q.; Ouyang, Y.; Mao, H.; Zhang, P.; Yao, J.; Xu, C.; Li, X.; Xiao, J.; Zhang, Q. A long noncoding RNA regulates photoperiod-sensitive male sterility, an essential component of hybrid rice. Proc. Natl. Acad. Sci. USA 2012, 109, 2654-2659. [CrossRef]

107. Ma, J.; Yan, B.Y.; Qin, F.; Yang, Y.; Hao, X.; Yu, J.; Zhao, Q.; Zhu, D.; Ao, G. Zm401, a short-open reading-frame mRNA or noncoding RNA, is essential for tapetum and microspore development and can regulate the floret formation in maize. J. Cell. Biochem. 2010, 105, 136-146. [CrossRef]

108. Song, J.H.; Cao, J.S.; Yu, X.L.; Xiang, X. BcMF11, a putative pollen-specific non-coding RNA from Brassica campestris ssp. chinensis. J. Plant Physiol. 2007, 164, 1097-1100. [CrossRef] 
109. Song, J.H.; Cao, J.S.; Wang, C.G. BcMF11, a novel non-coding RNA gene from Brassica campestris, is required for pollen development and male fertility. Plant Cell Rep. 2013, 32, 21-30. [CrossRef]

110. Ilott, N.E.; Ponting, C.P. Predicting long non-coding RNAs using RNA sequencing. Methods 2013, 63, 50-59. [CrossRef]

111. Fan, C.; Hao, Z.; Yan, J.; Li, G. Genome-wide identification and functional analysis of lincRNAs acting as miRNA targets or decoys in maize. BMC Genomics 2015, 16, 793. [CrossRef] [PubMed]

112. Ji, N.; Van, A.O. Single molecule fluorescent in situ hybridization (smFISH) of C. elegans worms and embryos. Wormbook 2012, 1-16. [CrossRef] [PubMed]

113. Lee, C.; Sorensen, E.B.; Lynch, T.R.; Kimble, J. C. elegans GLP-1/Notch activates transcription in a probability gradient across the germline stem cell pool. eLife 2016, 5, e18370. [CrossRef] [PubMed]

114. Rosa, S.; Duncan, S.; Dean, C. Mutually exclusive sense-antisense transcription at FLC facilitates environmentally induced gene repression. Nat. Commun. 2016, 7, 13031. [CrossRef] [PubMed]

115. Raj, A.; Van den Bogaard, P.; Rifkin, S.A.; Van Oudenaarden, A.; Tyagi, S. Imaging individual mRNA molecules using multiple singly labeled probes. Nat. Methods 2008, 5, 877-879. [CrossRef] [PubMed]

116. Mali, P.; Yang, L.; Esvelt, K.M.; Aach, J.; Guell, M.; DiCarlo, J.E.; Norville, J.E.; Church, G.M. RNA-guided human genome engineering via Cas9. Science 2013, 339, 823-826. [CrossRef] [PubMed]

117. Shechner, D.M.; Hacisuleyman, E.; Younger, S.T.; Rinn, J.L. Multiplexable, locus-specific targeting of long RNAs with CRISPR-Display. Nat. Methods 2015, 12, 664-670. [CrossRef] [PubMed]

118. Yang, Y.; Wen, L.; Zhu, H. Unveiling the hidden function of long non-coding RNA by identifying its major partner-protein. Cell Biosci. 2015, 5, 59. [CrossRef]

119. Li, R.; Fu, D.; Zhu, B.; Luo, Y.; Zhu, H. CRISPR/Cas9-mediated mutagenesis of $\backslash r$, lncRNA1459 \r, alters tomato fruit ripening. Plant J. 2018, 94, 513-524. [CrossRef]

120. Zhu, S.; Li, W.; Liu, J.; Chen, C.; Liao, Q.; Xu, P.; Xu, H.; Xiao, T.; Cao, Z.; Peng, J. Genome-scale deletion screening of human long non-coding RNAs using a paired-guide RNA CRISPR library. Nat. Biotechnol. 2016, 34, 1279-1286. [CrossRef]

121. Liu, S.J.; Horlbeck, M.A.; Cho, S.W.; Birk, H.S.; Malatesta, M.; He, D.; Attenello, F.J.; Villalta, J.E.; Cho, M.Y.; Chen, Y. CRISPRi-based genome-scale identification of functional long noncoding RNA loci in human cells. Science 2016, 355, eaah7111. [CrossRef] [PubMed]

122. Engreitz, J.M.; Haines, J.E.; Perez, E.M.; Munson, G.; Chen, J.; Kane, M.; Mcdonel, P.E.; Guttman, M.; Lander, E.S. Local regulation of gene expression by lncRNA promoters, transcription and splicing. Nature 2016, 539, 452-455. [CrossRef]

123. Tay, Y.; Rinn, J.; Pandolfi, P.P. The multilayered complexity of ceRNA crosstalk and competition. Nature 2014, 505, 344-352. [CrossRef] [PubMed]

124. Denzler, R.; Agarwal, V.; Stefano, J.; Bartel, D.P.; Stoffel, M. Assessing the ceRNA hypothesis with quantitative measurements of miRNA and target abundance. Mol. Cell 2014, 54, 766-776. [CrossRef] [PubMed]

125. Wang, J.; Liu, X.; Wu, H.; Ni, P.; Gu, Z.; Qiao, Y.; Chen, N.; Sun, F.; Fan, Q. CREB up-regulates long non-coding RNA, HULC expression through interaction with microRNA-372 in liver cancer. Nucleic Acids Res. 2010, 38, 5366-5383. [CrossRef] [PubMed]

126. Yuan, J.H.; Yang, F.; Wang, F.; Ma, J.Z.; Guo, Y.J.; Tao, Q.F.; Liu, F.; Pan, W.; Wang, T.T.; Zhou, C.C.; et al. A Long Noncoding RNA Activated by TGF- $\beta$ Promotes the Invasion-Metastasis Cascade in Hepatocellular Carcinoma. Cancer Cell 2014, 25, 666-681. [CrossRef]

127. Hu, Y.; Xu, J.; Fang, J.Y. Long noncoding RNA GAPLINC regulates CD44-dependent cell invasiveness and associates with poor prognosis of gastric cancer. Clin. Gastroenterol. Hepatol. 2015, 13, e100-e101. [CrossRef]

128. Kung, J.T.; Colognori, D.; Lee, J.T. Long noncoding RNAs: Past, present, and future. Genetics 2013, 193, 651-669. [CrossRef]

129. Lee, J.T. Epigenetic regulation by long noncoding RNAs. Science 2013, 21, 685-693. [CrossRef]

130. Yang, L.; Froberg, J.E.; Lee, J.T. Long noncoding RNAs: Fresh perspectives into the RNA world. Trends Biochem. Sci. 2014, 39, 35-43. [CrossRef]

(C) 2019 by the authors. Licensee MDPI, Basel, Switzerland. This article is an open access article distributed under the terms and conditions of the Creative Commons Attribution (CC BY) license (http:/ / creativecommons.org/licenses/by/4.0/). 